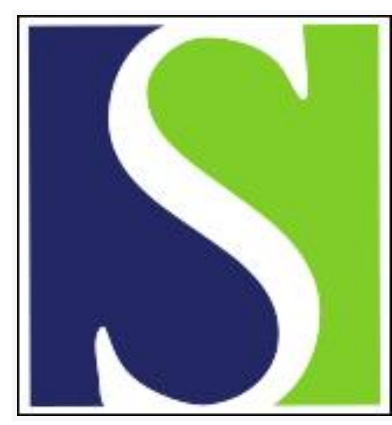

Scand J Work Environ Health 1998;24(4):276-284

https://doi.org/10.5271/sjweh.321

Issue date: Aug 1998

Immunologic and renal markers among photogravure printers exposed to toluene

by Stengel B, Cénée S, Limasset J-C, Diebold F, Michard D, Druet P, Hémon D

Key terms: antiglomerular basement membrane antibodies; antilaminin antibodies; beta ${ }_{2}$-microglobulin; enzymuria; epidemiology; immunoglobulin $\mathrm{E}$; longitudinal study; microalbuminuria; solvent

This article in PubMed: www.ncbi.nlm.nih.gov/pubmed/9754859

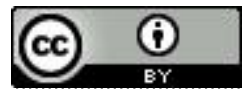




\title{
Immunologic and renal markers among photogravure printers exposed to toluene
}

\author{
by Bénédicte Stengel, PhD, ${ }^{1}$ Sylvie Cénée, BSc, Jean-Claude Limasset, PhD, ${ }^{2}$ François Diebold, MSc, ${ }^{2}$ \\ Denis Michard, MD, ${ }^{3}$ Philippe Druet, MD, ${ }^{4}$ Denis Hémon, $P h D^{4}$
}

\begin{abstract}
Stengel B, Cénée S, Limasset J-C, Diebold F, Michard D, Druet P, Hémon D. Immunologic and renal markers among photogravure printers exposed to toluene. Scand J Work environ Health 1998;24(4):276-284.

Objectives This study assessed immunologic and early renal effects of chronic toluene exposure.

Methods In a longitudinal study of 92 printers and 74 referents, 145 subjects had pre- and poststudy samples of blood and urine taken for the following measurements: immunoglobulin $\mathrm{E}(\mathrm{IgE})$, antiglomerular basement membrane (anti-GBM) and antilaminin (anti-LAM) antibodies in blood; creatinine and B2-microglobulin in blood and urine; and microalbumin, $N$-acetyl-b-D-glucosaminidase (NAG) and alanine-aminopeptidase in urine. Creatinine clearance was calculated according to the Cockroft-Gault formula. Eight-hour personal air samples were collected twice to assess present exposure to toluene. A job-exposure matrix was developed to estimate past cumulative exposure. Information about potential confounders was recorded by questionnaire. Multiple regression analysis was performed to study dose-effect relations adjusted for age and smoking.

Results No subject was positive for anti-GBM antibodies, and only 12 were positive for anti-LAM. No relation was observed between the markers studied and present exposure to toluene except that creatinine clearance was higher among the exposed subjects than among the referents. A dose-response relation was observed between cumulative toluene exposure and both IgE and NAG excretion. No interaction was observed between hypertension and exposure, but the relationship with NAG did not persist when subjects with hypertension were excluded. Past or present exposure did not alter the 2-year trend of any marker studied.

Conclusions According to the results of this study, toluene at $50 \mathrm{ppm}$ is not related to detectable renal dysfunction. The increased IgE levels associated with present and past exposure require further investigation.
\end{abstract}

Key terms antiglomerular basement membrane antibodies, antilaminin antibodies, B2-microglobulin, enzymuria, epidemiology, immunoglobulin $\mathrm{E}$, longitudinal study, microalbuminuria, solvent.

Several epidemiologic investigations have suggested that chronic exposure to organic solvents may play a role in the development of nephropathies and chronic renal failure (1), but the kinds of solvents involved and the mechanism of the renal damage are still unclear

Toluene is an aromatic hydrocarbon widely used in industry as a solvent for paints, varnishes, inks, and glues, as well as in the processing of numerous chemical products. Its acute toxicity to the renal tubule is fairly well documented, and inhalation of high doses of toluene (several thousand parts per million) has caused distal renal tubular acidosis $(2,3)$ among drug-users, sometimes with tubular proteinuria (4) or Fanconi's syndrome (5). A case of anti-glomerular basement-membrane antibody-mediated glomerulonephritis has also been reported for a young woman who sniffed glue for several weeks (6), and a case of focal segmental glomerulosclerosis was noted for a leather-worker exposed to toluene for 40 years (7).

Toluene nephrotoxicity at lower exposure levels, such as those usually encountered in occupational settings, is more controversial. The mortality study by Svensson et

1 INSERM U 170 (National Research Institute on Health and Medicine, Unit 170), Villejuif, France.

2 INRS, Vandoeuvre les Nancy, France.

3 Service Médical du Livre, Paris, France.

4 INSERM U 28 (National Research Institute on Health and Medicine, Unit 28) Hôpital Purpan, Toulouse, France.

Reprint requests to: Dr Bénédicte Stengel, INSERM U 170, 16 Av Paul Vaillant Couturier, F-94807 Villejuif cedex, France. [email: stengel@vjf.inserm.fr] 
al (8) was negative for printers, but their results were not conclusive because the study lacked power. Furthermore, mortality is a poor indicator of the incidence of renal disease now that renal replacement therapy exists. Crosssectional studies of various early markers of renal damage have been performed among populations exposed to toluene. Most of these studies concerned painters exposed to several solvents, but others involved printers whose solvent exposure was limited almost exclusively to toluene (table 1). The studies of painters have yielded contradictory results, glomerular and tubular renal alterations being found in 3 studies (9-11), tubular alterations only in 2 others $(12,13)$, and no effect in the final $2(14,15)$. Different exposure levels did not explain the variations. The study by Stevenson et al (16) also showed an increase in anti-glomerular basement membrane (antiGBM) and anti-laminin (anti-LAM) antibodies among exposed painters. The 2 studies in the printing industry were negative, but both concerned small samples (14, 17).

The objective of this study was to evaluate the renal effects of chronic toluene exposure among printers whose solvent exposure was limited to toluene and who were highly exposed to it. Several immunologic and renal markers were studied twice over a 2-year period to assess dose-effect relations with cumulative or present exposure, as well as trends.

\section{Subjects and methods}

\section{Population}

A longitudinal survey was carried out in a photogravure plant from January 1991 through May 1993. It included 166 male workers, 92 exposed to toluene and 74 referents. Those working with rotary printers (operators, handlers, winders), as well as retouchers and mechanics made up the exposed group. The reference group, stratified for age, comprised workers in the following 2 subgroups: (i) an internal reference group of subjects from the same plant $(\mathrm{N}=43)$, recruited from workers who were not directly exposed to toluene but were subjected to background exposure (engravers, fork-lift operators, compositors, and other unexposed personnel) and (ii) an external reference group $(\mathrm{N}=31)$ of unexposed workers from a binding plant that employed the same occupational physician as the printing plant.

All the subjects worked (8-hour) rotating shifts, spending successive weeks on day, evening, and night shifts. Those with diabetes or any renal disease (unrelated to exposure) were excluded. The study protocol included 2 examinations, the 1 st at study entry and the 2 nd 2 years later. Both examinations took place during a week that the subjects were working the day shift; each time, occupational nurses took blood and urine samples and measured the subjects' blood pressure. The subjects also

Table 1. Cross-sectional studies of renal markers among toluene-exposed workers. ( $U-\beta 2 M$ and $S-\beta 2 M=$ urinary and serum $\beta 2$ microglobulin, respectively; $\beta$ glu = Bglucuronidase; NAG = N-acetyl-b-glucuronidase; $R B P=$ retinol binding protein; $\gamma G T=$ gammaglutamyl-transférase; LAP = leucine-amino-peptidase; anti-GBM = anti-glomerular basement membrane antibodies; MEK = methyl ethyl ketone; TLV = threshold limit value; TWA = time-weighted average; NS = indicates no significant difference between the two groups)

\begin{tabular}{|c|c|c|c|}
\hline Study & Population & Exposure & Results ${ }^{a}$ \\
\hline Askergren et al, 1981 (14) & Photogravure printers (42 exposed, 48 referents) & Toluene ( 80 to $100 \mathrm{ppm}$ ) & Albuminuria (NS), U- $\beta 2 M$ (NS) \\
\hline Krusell et al, $1985(17)$ & Photogravure printers ( 39 exposed, 36 referents) & Toluene $(50 \% \mathrm{TLV})$ & Albuminuria (NS), U- $\beta 2 \mathrm{M}$ (NS) \\
\hline Askergren et al, 1981 (14) & Paint factory employees (40 exposed, 48 referents) & Toluene, xylene $(<40 \mathrm{ppm})$ & Albuminuria (NS), U- $\beta 2 \mathrm{M}$ (NS) \\
\hline Franchini et al, 1983 (12) & Painters (118 exposed, 81 referents) & Toluene, xylene $(25 \mathrm{ppm})$ & $\begin{array}{l}\text { Albuminuria (NS), lysozymuria } \uparrow \text {, } \\
\beta \text { glu } \uparrow\end{array}$ \\
\hline Lauwerys et al, 1985 (15) & Car painters ( 43 exposed, 43 referents) & White spirit toluene (2 ppm?) & $\begin{array}{l}\text { Albuminuria (NS), RBP (NS), } \\
\text { U- } \beta 2 M \text { (NS) }\end{array}$ \\
\hline Viau et al, 1987 (11) & Refinery employees (60 exposed, 69 referentls) & $\begin{array}{l}\text { Toluene (TWA }<3 \mathrm{ppm}) \\
\text { n-butane, n-pentane, n-hexane }\end{array}$ & $\begin{array}{l}\text { S- } \beta 2 M \uparrow \text {, serum immune } \\
\text { complex } \uparrow \text {, albuminuria } \uparrow \text {, } \\
\text { BB-50 } \uparrow, \text { U- } \beta 2 M \text { (NS), RBP (NS), } \\
\text { NAG (NS) }\end{array}$ \\
\hline Normand et al, 1990 (9) & $\begin{array}{l}\text { Paint factory employees ( } 271 \text { exposed, } 206 \\
\text { referents) }\end{array}$ & $\begin{array}{l}\text { Toluene (1/3 TLV), xylene, } \\
\text { MEK, white spirit, } \\
\text { trichlorethylene isobutanol, } \\
\text { lead, cadmium }\end{array}$ & $\begin{array}{l}\text { S-creatinine } \uparrow \text {, albuminuria } \uparrow \text {, } \\
\text { NAG (NS), RBP } \uparrow, \text { Tamm- } \\
\text { Horsfall (NS) }\end{array}$ \\
\hline $\mathrm{Ng}$ et al, $1990(13)$ & Painters (45 exposed, 45 referents) & Toluene $(<100 \mathrm{ppm})$ & $\begin{array}{l}\text { Albuminuria (NS), dose-effect } \\
\text { relationship between RBP and } \\
\text { U-o-cresol }\end{array}$ \\
\hline Yaqoob et al, $1993(10)$ & Paint sprayers (112 exposed, 105 referents) & $\begin{array}{l}\text { Toluene, xylene, and n-butyl } \\
\text { alcohol levels unknown }\end{array}$ & $\begin{array}{l}\text { S-creatinine } \uparrow \text {, total proteinuria } \uparrow \text {, } \\
\text { albuminuria (NS), NAG } \uparrow, \gamma G T \uparrow, \\
\text { LAP } \uparrow \text {, transferrin (NS), RBP(NS) }\end{array}$ \\
\hline Stevenson et al, $1995(16)$ & Paint sprayers ( $\uparrow 12$ exposed, 105 referents) & $\begin{array}{l}\text { Toluene, xylene, and n-butyl } \\
\text { alcohol levels unknown }\end{array}$ & $\begin{array}{l}\text { Soluble E-selectin } \uparrow \text {, anti-GBM } \\
\text { antibodies } \uparrow \text {, anti-laminin } \\
\text { antibodies } \uparrow\end{array}$ \\
\hline
\end{tabular}

\footnotetext{
a Comparison of exposed and unexposed subjects: the arrow $\uparrow$ indicates an increase in the mean or prevalence of elevated values among the exposed group when compared with the unexposed group.

b Specified only as within the occupation exposure limits of the United Kingdom at the time of the study.
} 
completed a self-administered questionnaire designed to provide information about their personal characteristics, tobacco and alcohol use, and overall health, specifically including known hypertension. Information about medication taken "at least once a day for at least a week during the past three months" was recorded with the aid of a list of potentially nephrotoxic drugs such as analgesics, nonsteroidal anti-inflammatory drugs, some antibiotics, and some antihypertensive and antiepileptic medications.

The subjects were 21 to 55 years of age. The exposed and reference groups were similar in mean age, body mass index, blood pressure, percentage with hypertension, percentage with asthma, alcohol use, and total length of employment (tables 2 and 3). The reference group contained proportionally more ex-smokers or heavy smokers and fewer subjects who stated that they had allergic rhinitis than did the exposed group. Fortyfive percent of the subjects had taken at least 1 drug regularly within the previous 2 months, and $27 \%$ had taken

Table 2. Subjects' age, body mass index, blood pressure, and duration of employment.

\begin{tabular}{|c|c|c|c|c|}
\hline & \multicolumn{2}{|c|}{$\begin{array}{l}\text { Exposed } \\
(N=92)\end{array}$} & \multicolumn{2}{|c|}{$\begin{array}{l}\text { Referents } \\
(N=74)\end{array}$} \\
\hline & Mean & $\mathrm{SD}$ & Mean & SD \\
\hline Age (years) & 38.7 & 11.9 & 40.0 & 9.8 \\
\hline Body mass index & 24.9 & 3.4 & 24.8 & 3.1 \\
\hline \multicolumn{5}{|l|}{ Blood pressure $(\mathrm{mm} \mathrm{Hg})^{a}$} \\
\hline $\begin{array}{l}\text { Systolic blood pressure }(\mathrm{mm} \mathrm{Hg}) \\
\text { Dlastolic blood pressure }(\mathrm{mm} \mathrm{Hg})\end{array}$ & $\begin{array}{r}129 \\
80\end{array}$ & $\begin{array}{r}12 \\
9\end{array}$ & $\begin{array}{r}132 \\
80\end{array}$ & $\begin{array}{r}14 \\
9\end{array}$ \\
\hline Duration of employment (years) & 16.3 & 13.1 & 16.9 & 12.2 \\
\hline
\end{tabular}

a $1 \mathrm{~mm} \mathrm{Hg} \approx 0.133 \mathrm{kPa}$.

Table 3. Subjects' smoking habits, alcohol consumption, drug intake, and health. (NSAID = nonsteroidal anti-inflammatory drug)

\begin{tabular}{|c|c|c|c|c|}
\hline & \multicolumn{2}{|c|}{$\begin{array}{l}\text { Exposed } \\
(\mathbb{N}=92)\end{array}$} & \multicolumn{2}{|c|}{$\begin{array}{l}\text { Referents } \\
(\mathrm{N}=74)\end{array}$} \\
\hline & $N$ & $\%$ & $N$ & $\%$ \\
\hline \multicolumn{5}{|l|}{ Smoking } \\
\hline Never smokers & 32 & 35 & 19 & 26 \\
\hline Ex-smokers & 20 & 22 & 29 & 39 \\
\hline$<20$ cigarettes per day & 25 & 27 & 10 & 13 \\
\hline$\geq 20$ cigarettes per day & 15 & 16 & 16 & 22 \\
\hline \multicolumn{5}{|l|}{ Alcohol } \\
\hline Never drinkers & 33 & 37 & 16 & 22 \\
\hline$<80$ g per day & 47 & 52 & 47 & 64 \\
\hline$\geq 80$ g per day & 10 & 11 & 11 & 15 \\
\hline Hypertension & 10 & 11 & 7 & 9 \\
\hline Asthma & 4 & 4 & 3 & 4 \\
\hline Allergic rhinitis & 13 & 14 & 3 & 4 \\
\hline \multicolumn{5}{|l|}{ Drug intake } \\
\hline Glafenine & 7 & 9 & 4 & 7 \\
\hline NSAID & 7 & 9 & 9 & 15 \\
\hline Paracetamol & 10 & 13 & 15 & 23 \\
\hline Antibiotics & 11 & 12 & 10 & 14 \\
\hline
\end{tabular}

at least 1 analgesic (glafenine, paracetamol, aspirin, or an nonsteroidal anti-inflammatory drug); these percentages did not differ between the 2 groups.

During the protocol development, 1 year before the study started, the company hired 18 subjects who had never been occupationally exposed to solvents. Each provided a urine sample as part of their preemployment medical examination, and 2 further urine samples as part of the study, and all 3 samples were considered in this analysis.

\section{Immunologic and renal markers}

Samples. Ten milliliters of blood was sampled for the assays of creatinine, B2-microglobulin, immunoglobulin $\mathrm{E}$ (IgE), and anti-GBM and anti-LAM antibodies. A spot urine sample (first of the morning) was collected to assay creatinine, microalbumin, B2-microglobulin, $\mathrm{N}$ acetyl-ß-D-glucosaminidase (NAG), and alanine-aminopeptidase (AAP). To limit physiological sources of variation, standardized methods were used for collecting the urine and performing the assays. For both sets of tests, sampling took place weekly over a 2 -month period and involved, on each occasion, the same proportion of exposed and reference subjects. All biochemical measurements, including those for the 18 subjects examined when hired, were performed in the same laboratory, within 8 hours of sample collection. To alkalinize the urine and thus prevent degradation of the 82 -microglobulin, the subjects drank a 33-cl bottle of alkaline water (Vichy Saint-Yorre) the evening before the testing.

Assays. The Cobas Bio centrifugal autoanalyzer (Roche, Neuilly, France) was used for measuring creatinine, NAG, and AAP, and a Laser BN 100 nephelometer (Behring, Rueil Malmaison, France) measured microalbumin. The assay methods included the kinetic Jaffé reaction for creatinine, immunoprecipitation for microalbumin, enzyme immunoassay (MEIA) for B2-microglobulin (IMx B2-microglobulin test, Abbott-France, Rungis), hydrolysis of 3-cresolsulfonphtaleinyl-N-acetyl-b-D-glucosaminide (Boehringer France, Meylan) for NAG, and hydrolysis of L-alanine-4-nitroanilide (Merck, Paris, France) for AAP. Individual differences in urine dilutions were taken into account by relating the data to creatinine concentration. Creatinine clearance was calculated with the Cockcroft-Gault formula (18). Relative B2-microglobulin clearance, defined as the ratio of 32 -microglobulin clearance to creatinine clearance, was also calculated. According to Järup et al (19), values of 0.1$2.5 \%$ indicate slight tubular dysfunction, and those above $2.5 \%$ reveal severe dysfunction. The anti-GBM and antiLAM antibodies were assessed with an enzyme-linked immunosorbent assay adapted from an assay described previously in a rat model (20). Collagenase-digested human GBM and Englebreth-Holm-Swarm (EHS) mouse 
sarcoma laminin (Sigma, St Louis, MO, USA) were used as antigens. Sera from 300 healthy blood donors served as reference. Serum samples from the study subjects were tested at dilutions of 1/10,1/100 and 1/1000. Abnormal values for each antigen were defined as equal to or greater than the blood donor mean +3 SD. As positive referents, we used, for the anti-GBM assay, serum from a patient with Goodpasture's syndrome and, for the anti-LAM assay, serum from a rat with autoimmune glomerulonephritis induced by exposure to mercury chloride (20). IgE was assayed with a Biotrol Kit (Biotrol, Paris).

The blood and urine analyses were performed twice, at the beginning and end of the study, for 145 subjects ( 82 exposed, 63 referents). For technical reasons, $32-\mathrm{mi}$ croglobulin measures were not available at the time of the 2nd examination. Anti-GBM and anti-LAM antibodies were assessed only once.

\section{Toluene exposure}

Current exposure assessment. Personal air sampling in the breathing zone was performed in March 1991 and June 1992, for 1 workweek each time. It covered all jobs, on all shifts, for all subjects who worked at the printing plant, whether directly or indirectly exposed. Air samples were collected on charcoal tubes (SKC ref 22601 ) with constant-flow $(50 \mathrm{ml} / \mathrm{mn})$ portable pumps over an 8-hour shift. After desorption with carbon disulfide, the toluene content was analyzed by gas chromatography with flame ionization detection. Overall, 85 of the 92 exposed subjects had at least 1 air sample taken, and 47 had 2 samples taken. Of the 43 internal referents at the printing plant, 26 had at least 1 measurement, and 19 had 2 measurements so that the background level of toluene exposure could be assessed. Since no change in work conditions occurred between the 2 periods, these measurements were considered to reflect the mean exposure levels during the study. The current toluene exposure level was defined as the mean of the measurements for subjects with 2 samples and as the value measured for those who had only 1 sample. The 7 exposed subjects and 17 referents without air sampling were attributed the mean value of all subjects with measurements in the same workplace. The exposure level of the external referents was assumed to be zero.

The pressmen were, on the average, exposed to a toluene level half that of the French time-weighted average occupational exposure limit [ie, $375 \mathrm{mg} / \mathrm{m}^{3}(100 \mathrm{ppm})$ ], but there were substantial variations from this mean depending on the machine to which they were assigned (table 4). Exposure levels for the other exposed jobs were approximately a $3 \mathrm{rd}$ of the occupational exposure limit. For the referents within the company, background exposure was highest for the forklift operators, about onetenth of the occupational exposure limit, and lower for the other referents.
Assessment of past exposure to toluene and to total hydrocarbons. The company's records allowed us to establish the history of their printing techniques. Letterpress printing ended in 1970, typesetting in 1979, and off-set printing in 1980. Photogravure techniques, especially the composition of the ink-diluting solvents, also changed. Benzene disappeared from the formulation in 1952. Until 1968, the diluting solvent was a mixture of spirits composed of aromatic solvents (naphtha petroleum distillates) containing toluene and xylene. Starting in 1968, the toluene content of ink solvents increased, reaching $98 \%$ in 1982. The company had also used several generations of presses. The following 2 dates mark important changes in the work conditions of the plant: (i) 1974: systems for solvent recovery and air exchange began to be installed on some machines and (ii) 1982: giant printing presses went into operation; some were enclosed and located in a small building, others were not enclosed and were located in large workshops.

Since 1960, regular area samples of both toluene and total hydrocarbon concentrations have been collected at a fixed point near each press twice a year. Sampling lasts an average of 3 hours. The samples are collected with charcoal tubes and analyzed with a gas chromatograph, a method that is very similar to that used for personal sampling in this study. These measurements allowed us to calculate the annual mean exposure to toluene and total hydrocarbons among the printers who worked on different generations of machines and thus to develop a jobexposure matrix. The detailed work history of each subject within the plant was recorded on a self-administered questionnaire. Combining the work histories and the matrix allowed us to assign each printer the mean of the measurements for his machine for a given year. No past area measurements were available for jobs that were not associated with a specific machine. Thus there were no measurements for mechanics and engravers, for

Table 4. Toluene exposure level $\left(\mathrm{mg} / \mathrm{m}^{3}\right)$ in the photogravure plant according to work assignment at the time of the study. ( $N=$ number of measurements, $\mathrm{GM}=$ geometric mean, $\mathrm{GSD}=$ geometric standard deviation)

\begin{tabular}{lrrr}
\hline Job assignment & $\mathrm{N}$ & GM & GSD \\
\hline Exposure jobs & & & \\
$\quad$ Photogravure pressmen & 103 & 152 & 2.0 \\
$\quad$ Printing press 1 & 52 & 232 & 1.7 \\
$\quad$ Printing press 2 & 48 & 97 & 1.7 \\
$\quad$ Printing press 3 & 3 & 143 & 1.4 \\
Other exposed jobs & 29 & 109 & 1.6 \\
$\quad$ Total & 132 & 141 & 1.9 \\
Control jobs within photogravure plant & & & \\
$\quad$ Forklift operators & 15 & 34 & 2.1 \\
Compositors & 12 & 23 & 2.0 \\
Engravers & 7 & 24 & 2.0 \\
$\quad$ Other & 11 & 27 & 1.9 \\
Total & 45 & 27 & 2.0 \\
\hline
\end{tabular}


example, whether or not they were exposed. To estimate past exposure for these jobs, we used the data from the 2 sets of personal measurements taken in 1991 and 1992 and calculated the relation between these exposure levels and that of the printers for each job category. On the assumption that this ratio remained stable over time, we then assessed past exposure for each category, using the ratio with the mean of the measurements available for each year for the printers overall. A cumulative exposure index $\left(\mathrm{mg} / \mathrm{m}^{3} \times\right.$ years $)$ was calculated for all the printing plant subjects by summing these estimated annual exposures.

Exposure to toluene and total hydrocarbons decreased considerably between 1960-1973 and 1974-1982 (table 5). Since 1983, toluene has been the main solvent in inks, and levels of exposure have decreased more slowly, but regularly, through 1991. In 1991, the toluene exposure level assessed by regular area sampling was lower than that observed with personal air sampling in this study.

\section{Statistical methods}

The serum creatinine and B2-microglobulin and creatinine clearance were normally distributed. The other variables had skewed distributions and were log-

Table 5. Past toluene and total hydrocarbon exposure level $\left(\mathrm{mg} / \mathrm{m}^{3}\right)$ in the photogravure plant, by period of exposure. $(\mathrm{N}=$ number of measurements, $\mathrm{GM}=$ geometric mean, $\mathrm{GSD}=$ geometric standard deviation)

\begin{tabular}{lrrrrrrrr}
\hline Period of exposure & \multicolumn{3}{c}{ Toluene exposure } & & \multicolumn{3}{c}{$\begin{array}{c}\text { Total hydrocarbon } \\
\text { exposure }\end{array}$} \\
\cline { 2 - 3 } \cline { 6 - 7 } & N & GM & GSD & & N & GM & GSD \\
\hline $1960-1973$ & 215 & 134 & 3.3 & & 217 & 905 & 2.6 \\
$1974-1982$ & 222 & 104 & 2.6 & & 169 & 210 & 2.2 \\
$1983-1989$ & 258 & 100 & 2.1 & & & \\
$1990-1991$ & 24 & 89 & 2.0 & & & \\
\hline
\end{tabular}

transformed. An analysis of variance and multiple regression were used to compare the mean values of the markers at the beginning of the study and their trend over 2 years for the exposed and reference subjects. For the normally distributed variables, the trend between the 2 measurements was evaluated by the difference between the 2 values; for the other variables, the ratio of the 2 corresponding median values was used. A matched analysis of variance was used to test the overall trend of the markers between the 2 periods and to compare the values of the markers before and after employment began for the 18 subjects who provided samples when hired.

Multiple regression was used to study the dose-effect relations between the markers and current toluene exposure, length of employment in a given exposed job, and cumulative exposure to toluene and total hydrocarbons. The exposure units used were (i) 5-year periods for length of employment in an exposed job, (ii) $37.5 \mathrm{mg} / \mathrm{m}^{3}$ (ie, $10 \mathrm{ppm}$ ) for current exposure to toluene, (iii) $375 \mathrm{mg} / \mathrm{m}^{3}$ $\times$ years (that is, $100 \mathrm{ppm} \times$ years) for cumulative exposure to toluene, and (iv) $375 \mathrm{mg} / \mathrm{m}^{3} \times$ years for cumulative exposure to total hydrocarbons.

The relations between the markers and the exposure indicators were adjusted for age (quantitative) and for smoking (in the 4 categories of nonsmokers, ex-smokers, $<20$ cigarettes/day, $\geq 20$ cigarettes/day). They were also adjusted for body mass index (quantitative) when serum creatinine was analyzed.

Four referents had previously held jobs considered to be exposed in the plant. Variance analysis was performed both with and without these subjects. In the multiple regression analysis, all the referents were included. Duration and cumulative exposure were set at 0 for all but the 4 subjects with past exposure, which was thus taken into account in the study of dose-effect relations.

To test whether an interaction existed between hypertension and exposure, the analysis was repeated with an interaction term between hypertension and the

Table 6. Serum and urinary biomarkers and renal function at the start of the study and the variation over a 2-year period. (LAM = laminin, GBM =

\begin{tabular}{|c|c|c|c|c|c|c|c|c|c|c|c|}
\hline & \multirow[t]{2}{*}{$N$} & \multirow{2}{*}{$\begin{array}{l}\text { Anti-LAM } \\
\text { antibodies } \\
(\%)\end{array}$} & \multirow{2}{*}{$\begin{array}{l}\text { Anti-GBM } \\
\text { antibodies } \\
(\%)\end{array}$} & \multicolumn{2}{|c|}{$\begin{array}{l}\lg E^{b} \\
(\mid \mathrm{U} / /)\end{array}$} & \multicolumn{2}{|c|}{$\begin{array}{c}\beta 2 \text {-microglobulinc } \\
(\mu \mathrm{g} / \mathrm{l})\end{array}$} & \multicolumn{2}{|c|}{$\begin{array}{l}\text { Creatininec } \\
(\mu \mathrm{mol} / \mathrm{l})\end{array}$} & \multicolumn{2}{|c|}{$\begin{array}{l}\text { Creatinine clearance } e^{\mathrm{s},} \\
\qquad(\mathrm{m} / \mathrm{min})\end{array}$} \\
\hline & & & & $\mathrm{GM}$ & GSD & $\mathrm{AM}$ & SD & $A M$ & SD & $\mathrm{AM}$ & $S D$ \\
\hline \multicolumn{12}{|l|}{ First examination } \\
\hline Exposed subjects & 92 & 7.6 & 0 & 96.3 & 2.9 & 1203 & 237 & 92.8 & 11.7 & 102.4 & $18.4^{*}$ \\
\hline Referents & 74 & 8.1 & 0 & 84.3 & 2.6 & 1187 & 246 & 95.4 & 11.6 & 95.9 & 16.4 \\
\hline \multicolumn{12}{|l|}{ Variation over 2 years $s^{b, c}$} \\
\hline Exposed subjects & 82 & - & - & 1.8 & 1.8 & +383 & 442 & 4.6 & 13.4 & -5.8 & 14.9 \\
\hline Referents & 63 & - & - & 1.6 & 2.3 & +336 & 395 & +3.6 & 11.6 & -4.1 & 12.1 \\
\hline
\end{tabular}

a Percentage of positive serum.

b Log-transformed variables: figures are the geometric mean (GM) and geometric standard deviation (GSD) for the 1st examination and the ratio of the 2nd: 1st

- Normally distributed variables: figures are arithmetic mean (AM) and standard deviation (SD) for the 1st examination, and the difference between the mean

d Creatinine clearance calculated according to the Cockroft-Gault formula (17).

e Only for subjects with a urinary pH of $\geq 6$ (ie, 62 exposed subjects and 55 referents).

* $P=0.02$, comparison between the exposed subjects and the referents. 
Table 7. Comparison of the urinary marker mean values before and after 1 and 3 years of toluene exposure among the 18 newly employed printers. $(\mathrm{GM}=$ geometric mean, $\mathrm{GSD}=$ geometric standard deviation, $N A G=N$-acetyl- $\beta$-glucuronidase, $A A P=$ alanine aminopeptidase)

\begin{tabular}{|c|c|c|c|c|c|c|}
\hline \multirow[t]{2}{*}{$\begin{array}{l}\text { Urinary } \\
\text { marker }\end{array}$} & \multicolumn{2}{|c|}{$\begin{array}{l}\text { Before } \\
\text { exposure } \\
(\mathbb{N}=18)\end{array}$} & \multicolumn{2}{|c|}{$\begin{array}{l}\text { Atter } 1 \text { year } \\
\text { of exposure } \\
(\mathbf{N}=18)\end{array}$} & \multicolumn{2}{|c|}{$\begin{array}{l}\text { After } 3 \text { years } \\
\text { of exposure } \\
(N=15)\end{array}$} \\
\hline & GM & GSD & $\mathrm{GM}$ & GSD & GM & GSD \\
\hline $\begin{array}{l}\text { Creatinine (mmol/l) } \\
\text { Microalbumin }\end{array}$ & 18.2 & 1.6 & 17.6 & 1.4 & 17.3 & 1.3 \\
\hline (mg/mmol creatinine) & 0.68 & 1.9 & 0.52 & 2.1 & 0.55 & 2.3 \\
\hline NAG (UI/mmol creatinine) & 0.15 & 1.2 & 0.17 & 1.4 & 0.16 & 1.4 \\
\hline AAP (UI/mmol creatinine) & 0.50 & 1.3 & 0.52 & 1.2 & 0.53 & 1.2 \\
\hline
\end{tabular}

Nonetheless, although the risk of bias is indeed high in the study of a clinical disorder, it is unlikely in a study of subclinical events that have not been monitored at all in the company, as was the case for the renal markers studied here. The lack of any discernible change among the newly hired printers, even though there were few, is another argument against the existence of such bias.

Recruiting half the referents within the company might also have resulted in an underestimation of the difference between the exposed and reference groups, because of the background exposure of the latter. However, the 2 reference groups did not differ except for their concentration of serum B2-microglobulin, and it was higher among the external referents than among the internal group. Thus a wholly external reference group would not have altered the conclusions about this marker. In addition, the exposure of the internal referents contrasted markedly with that of the printers and was only one-fifth as high. This choice of referents did not affect the investigation of the dose-effect relation either, since, overall, the study subjects present a wide range of exposure. The 1991 regular area measurements showed lower toluene exposure levels than did the personal air samples measured simultaneously as part of this study. This finding suggests that the area measurements may have been underestimating subjects' exposure, which in turn may have affected cumulative exposure estimates and thus resulted in an underestimation of its effect.

Particular attention was paid to the comparability of the groups in this study, by choosing the referents and sampling methods with special care, as well as by reducing the physiological factors of marker variation. Risk of bias related to socioeconomic status cannot be suspected because the referents were recruited among workers in the same occupational activity. All the subjects were male, and the groups were comparable for age. The referents, like the exposed subjects, worked rotating shifts and were all tested during a week on the day shift; thus any differences due to circadian effects on the urinary markers were avoided $(21,22)$. The subjects were examined under identical conditions, and the samples were not stored. Both of these factors limited any preanalytic variations between the subjects. Subjects with hypertension were not systematically excluded, so that we could study the possibility of an interaction between hypertension and exposure, as suggested by Hotz et al (23). No significant interaction was observed, but, when the subjects with hypertension were excluded, the relation between cumulative toluene exposure and urinary NAG, which was at the borderline of statistical significance, disappeared. Finally, among the external factors of marker variation, as reported elsewhere (24), only smoking differed between the 2 groups, and it was systematically taken into account in the study of exposure-marker relations.

This study is, as far as we know, the first to use renal markers to examine past and present exposure to toluene and other hydrocarbons in such detail for this occupational activity. It was able to show a difference of 5 $\mathrm{mmol} / \mathrm{l}$ in serum creatinine between the exposed and reference subjects, with a risk of error of $5 \%$ and a power of $80 \%$, and a difference, respectively, of $107 \mathrm{mg} / \mathrm{l}$ and $7 \mathrm{ml} / \mathrm{min}$ for serum 32 -microglobulin and creatinine clearance. For the log-transformed parameters, it could have shown a $39 \%$ difference between the exposed and reference subjects in the mean level of microalbumin, $24 \%$ for the 32 -microglobulin and NAG levels and $20 \%$ for AAP.

Other questions may be raised about the renal markers studied and their sensitivity. We chose to investigate 1 early marker of glomerular damage (microalbumin) and 3 early markers of damage to the proximal tubule ( $B 2-$ microglobulin and 2 enzymes, NAG and AAP). The sensitivity of these 4 markers is unknown from an epidemiologic point of view. Nonetheless, studies over the past 20 years in various populations exposed to solvents or metals have shown that microalbumin, NAG, and AAP are capable of detecting groups at risk (25). For a long time, B2-microglobulin was the only low-molecularweight protein used as a marker of tubular damage, but it is now often replaced by retinol-binding protein or $\alpha$ 1 -microglobulin, more stable in acid pH (26). However, the efficacy of 32 -microglobulin as a marker was recently proved again in the demonstration of a dose-effect relation with cadmium exposure (27). In our study, despite absorption of sodium bicarbonates, approximately a $3 \mathrm{rd}$ of the subjects in both groups had a $\mathrm{pH}$ of $<6$. Their exclusion from the analysis increased the mean of this marker but did not modify its relation to exposure. We also assessed the relative 32 -microglobulin clearance, which is considered a sensitive marker of tubular dysfunction by some authors (19). It was not related to exposure in this study.

Our results for the biochemical markers are comparable only with those in the studies by Askergren et al (14) and Krusell et al (17), who measured urinary 
excretion of albumin and $\beta 2$-microglobulin among print ers whose characteristics were similar to those of the population we studied. The power of these 2 negative studies is nonetheless questionable. In other studies (table 1), the subjects were painters exposed to various solvents and sometimes also to lead and cadmium (9). In the studies that observed a significant increase in the urinary excretion of some of the renal markers, the effect of toluene could not be isolated.

In view of the lesions that have been described for acute toluene toxicity, which differs from those due to other hydrocarbons, a study of a marker of damage to the distal tubule would have been interesting and might have improved our understanding of the mechanism of renal damage. There are, however, very few such markers, and they are not yet well understood in an epidemiologic context. Only Normand et al (9) have so far studied the urinary excretion of Tamm-Horsfall glycoprotein. They did not observe any change in this variable in relation to the painters' exposure to toluene.

The roles of organic solvents in glomerular nephropathies have been the subject of many studies over the past 20 years. Forty cases of rapidly progressive glomerulonephritis (Goodpasture's syndrome) and of chronic nephropathies have been reported and associated with exposure to various solvents (28); 2 of these cases involved toluene $(6,7)$. Fifteen case-referent studies have been performed during that time, 12 of which showed an association between chronic glomerular nephropathies and solvent exposure (1). An explanation of the mechanism by which solvents act has yet to be furnished. The most recent proposals suggest that solvents may play a role in the progression of a nephropathy towards chronic renal failure $(29,30)$.

This study also analyzed 3 immunologic markers, anti-GBM antibodies, which are specific to the glomerular damage of Goodpasture's syndrome, anti-LAM antibodies, which have been found in autoimmune glomerulonephritis induced by exposure to mercury chloride among rats, and total IgE, which indicates type I hypersensitivity. Unlike Stevenson et al (16), we did not observe any increase in these antibodies with toluene exposure. This difference may have been due to exposure differences between the 2 populations or to the threshold chosen to define positive subjects. IgE did increase significantly with cumulative toluene exposure, a modification that is not explained by a higher frequency of allergic events. As far as we know, no hypersensitivity to toluene has been described.

In conclusion, this study found no indication that toluene at the current mean exposure level of $50 \mathrm{ppm}(50 \%$ of the French occupational exposure limit) is related to renal dysfunction in this plant. The observation that the IgE concentration increased with cumulative exposure to toluene requires confirmation.

\section{Acknowledgments}

This study received financial support from the Ministry of Research and Technology.

We are grateful to Dr F Marlin, occupational physician, and to Mrs C Prévost, A Forestier, and M Neels, nurses in the medical department of the printing plant, for their crucial participation in the data collection. We also thank Jo Ann Cahn for translating this paper.

\section{References}

1. Hotz P. Occupational hydrocarbon exposure and chronic nephropathy. Toxicology 1994;90:163-283.

2. Taher SM, Anderson RJ, Mac Cartney R, Popovtzer MM, Schrier RW. Renal tubular acidosis associated with toluene "sniffing". N Engl J Med 1974;290(14):765-8.

3. Fischman CM, Oster JR. Toxic effects of toluene: a new cause of high anion gap metabolic acidosis. JAMA 1979;241(16):1713-5.

4. Kamijima M, Nakazawa Y, Yamakawa M, Shibata E, Hisanaga N, Ono $Y$, et al. Metabolic acidosis and renal tubular injury due to pure toluene inhalation. Arch Environ Health 1994:49:410-3.

5. Moss AH, Gabow PA, Kaehny WD, Goodman SI, Haut LL Fanconi's syndrome and distal renal tubular acidosis after glue sniffing. Ann Intern Med 1980;92:69-70.

6. Bonzel KE, Muller-Wiefel DE, Ruder H, Wingen AM, Waldherr R. Weber M. Anti-glomerular basement membrane antibody-mediated glomerulonephritis due to glue sniffing. Eur J Pediatr 1987;146(3):296-300.

7. Bosch X, Campistol JM, Montoliu J, Revert L. Myelofibrosis and focal segmental glomerulosclerosis associated with toluene poisoning. Hum Toxicol 1988;7(4):357-61.

8. Svensson BG, Nise G, Englander V, Attewell R, Skerfving S, Moller $\mathrm{T}$. Deaths and tumors among rotogravure printers exposed to toluene. Br J Ind Med 1990;47:372-9.

9. Normand JC, Bernard A, Buchet JP, Roels H, Michaux J, de Wandeler $\mathrm{V}$, et al. Recherche d'anomalies rénales infracliniques chez les travailleurs de deux entreprises productrices de peintures. Arch Mal Prof 1990;51:261-6.

10. Yaqoob M, Bell GM, Stevenson A, Mason H, Percy DF. Renal impairment with chronic hydrocarbon exposure. Q J Med 1993;86:165-74.

11. Viau C, Bernard A, Lauwerys R, Buchet JP, Quaeghebeur L, Cornu ME, et al. A cross-sectional survey of kidney function in refinery employees. Am J Ind Med 1987;11(2):177—87.

12. Franchini I, Cavatorta A, Falzoi M, Lucertini S, Mutti A Early indicators of renal damage in workers exposed to organic solvents. Int Arch Occup Environ Health 1983;52(1):1 —9

13. Ng TP, Ong SG, Lam WK, Jones MG, Cheung CK, Ong CN Urinary levels of proteins and metabolites in workers exposed to toluene: a cross-sectional study. Int Arch Occup Environ Health 1990;62(1):43-6.

14. Askergren A, Allgen LG, Karlsson C, Lundberg I, Nyberg E. Studies on kidney function in subjects exposed to organic solvents, I: excretion of albumin and beta-2-microglobulin in the urine. Acta Med Scand 1981;209(6):479-83.

15. Lauwerys R, Bernard A, Viau C, Buchet J-P. Kidney disorders and hematotoxicity from organic solvent exposure. Scand 
J Work Environ Health 1985;11 suppl 1:83-90.

16. Stevenson A, Yaqoob M, Mason H, Pai P, Bell GM. Biochemical markers of basement membrane disturbances and occupational exposure to hydrocarbons and mixed solvents. Q J Med 1995;88:23—-8.

17. Krusell L, Nielsen HK, Baelum J, Lundqvist G, Omland O, Vaeth M, et al. Renal effects of chronic exposure to organic solvents: a clinical controlled trial. Acta Med Scand 1985;218:323-7.

18. Cockroft DM, Gault MH. Prediction of creatinine clearance from serum creatinine. Nephron 1976;16:31- 41.

19. Järup L, Persson B, Elinder C-G. Decreased glomerular filtration rate in solderers exposed to cadmium. Occup Environ Med 1995;52:818-22.

20. Guéry JC, Druet E, Glotz D, Hirsch F, Mandet C, De Heer E, et al. Specificity and cross-reactive idiotypes of anti-glomerular basement membrane autoantibodies in $\mathrm{HgCl}$-induced autoimmune glomerulonephritis. Eur J Immunol 1990;20:93100.

21. Boogaard PJ, Caubo MEJ. Inreased albumin excretion in industrial workers due to shift work rather than to prolonged exposure to low concentrations of chlorinated hydrocarbons. Occup Environ Med 1994;51:638-41.

22. Burchardt U, Jung K. Physiological factors influencing enzyme excretion. In: Jung K, Mattenheimer $\mathrm{H}$, Burchardt $\mathrm{U}$, editors. Urinary enzymes in clinical and experimental medicine. Berlin: Springer-Verlag, 1992:73 - 86.

23. Hotz P, Pilliod J, Bernard A, Berode M, Rey F, Mazzocato C, et al. Hydrocarbon exposure, hypertension and kidney function tests. Int Arch Occup Environ Health 1990;62:501-8.
24. Stengel B, Chouquet C, Cénée S, Philippon C, Michard D, Hémon D. Marqueurs précoces de néphrotoxicité: facteurs de variation et reproductibilité. Rev Epidémiol Santé Publ 1995;43:494-503.

25. Price RG, Taylor SA, Chivers I, Arce-Tomas M, Crutcher E, Franchini I, et al. Development and validation of new screening tests for nephrotoxic effects. Hum Exp Toxicol 1996;15 suppl 1:S10-9.

26. Jung $K$. Urinary enzymes and low molecular weight proteins as markers of tubular dysfunction. Kidney Int 1994;46 suppl 47:\$29-33.

27. Järup L, Persson B, Elinder C-G. Blood cadmium as an indicator of dose in a long-term follow-up of workers previously exposed to cadmium. Scand J Work Environ Health 1997;23:31-6.

28. Bombassei GJ, Kaplan AA. The association between hydrocarbon exposure and anti-glomerular basement membrane antibody-mediated disease (Goodpasture's syndrome). Am J Ind Med 1992;21(2):141—53.

29. Stengel B, Cénée S, Limasset JC, Protois JC, Marcelli A, Brochard $P$, et al. Organic solvent exposure may increase the risk of glomerular nephropathies with chronic renal failure. Int J Epidemiol 1995;24:427-34.

30. Yaqoob M, Stevenson A, Mason H, Bell GM. Hydrocarbon exposure and tubular damage: additional factors in the progression of renal failure in primary glomerulonephritis. Q $\mathbf{J}$ Med 1993;86:661-7.

Received for publication: 30 July 1997 